3）小林恭子, 藤下 一, 佐藤孝幸, 中山寿昌, 戸田昭三, 分析化学, 39, 835 (1990).

4) S. Asaumi, T. Nakayama, Y. Kitani and A. Yokoa,
Proc. 6th Symposium on Automated Integrated Circuits Manufacturing, 335 (1991).

\title{
電解コンデンサー用アルミ箔の 液中給電化成技術の開発と実用化
}

\section{1 緒 言}

アルミ電解コンデンサーは, セラミックコンデンサー 及びタンタルコンデンサーと並び称される三大コンデン サーの一つであり，民生用電子機器類の回路の多機能化 による二次側回路用低圧コンデンサー $($ ～100 V) 並び に電子機器の小型化及び省エネ化のためのインバーター 化による一次側電源回路用中高圧コンデンサー $(200 \sim 400$ V) の大幅な需要の伸びに支えられ，その生産量は年々 増加する傾向にある.これに呼応してアルミ電解コンデ ンサーに用いられる電解酸化アルミ箔（化成アルミ箔） の生産量毛年々大きく增加してきている. 電解コンデン サー用アルミ箔は, 電気化学的なエッチングにより表面 積を拡大したアルミ䈃 (エッチド箔) の表面に, さらに 電気化学的に酸化アルミニウム誘電体被膜を形成させる ための連続電解化成処理工程を経て製造される.

アルミ箔連続電解化成処理方法としては, Fig. 1 K 示すような金属製給電ロールを直接アルミ箔に接触させ て給電する方法（ロール給電法又は接触給電法之呼ばれ る）が従来用いられていた。しかしながら，この接触給 電法では，金属ロールを介してアルミ箔に給電する際， アルミ箔と金属ロールとの接触面積が小さいために，大 電流を流すとジュール熱による局部的な発熱が生じ，了 ルミ箔が溶融したり，時にはアルミ箔が溶断するなどの 問題が頻繁に起きていた。このため,コンデンサー用ア ルミ箔の需要增加に合わせて化成馢を增産する場合, ラ イン当たりの通電量を増やして電解処理量を増やすとい うことができず，コンデンサーメーカーとしてはこれ迄 止むなく莫大な新規設備投資を行なってきた。

一方, Fig. 2 に示すような電解液を介してアルミ箔 に間接的に給電する方法，いわゆる液中給電法（液体給 電法又は無接触給電法とも呼ばれる）はアルミ箔に直接

ペルメレック電極㑣（穴252 藤沢市遠藤 2023-15）

†マルコン電子(侏（尔993 長井市幸町 1-1）

\section{（技術賞・棚橋賞） \\ 中島 保夫*, 島宗 孝之, 中松 秀司 \\ 山川 禎康 ${ }^{\dagger}$, 狆山 俊朗 ${ }^{\dagger}$, 船越 明 ${ }^{\dagger}$}

電気接点がとられないために, ロール給電法に比ベアル ミ箔の溶断問題が無〉なるなど, 高速連続電解化成処理 法としては非常に優机た面を持っている.

この液中給電法は、ロール給電法による既存の化成機 （ライン）の一部を改造するだけで比較的容易に液中給 電法に切り替えるこにができるので, ラインの新設に比 べて工事期間は短く，また設備投資額屯遥かに小さくて 済むなどの利点を兼㸚備えた電解化成法である。

液中給電化成技術自体は, 既に 1950 年代から提唱さ れている技術ではあるがは4)，コンデンサー用アルミ箔 化成法への適用に際しては, 化成電解液として用いられ る有機酸水溶液を酸化分解させずに, 水の分解反庍を選 択優先的に行ない給電のみを行うことのできる陽極が無 かったこと, 並びに䘸中給電槽中のアルミ箔の陰分極に よる水素脆化の影響を抑制する方法が見い出せなかった ことなどにより，これ迄実用化されなかった．

筆者らは, 上述の問題を解決するために種々の複合酸 化物被覆金属電極を検討した結果, 近年酸素発生用DSE として広く知られるようになった低酸素過電圧電極特性

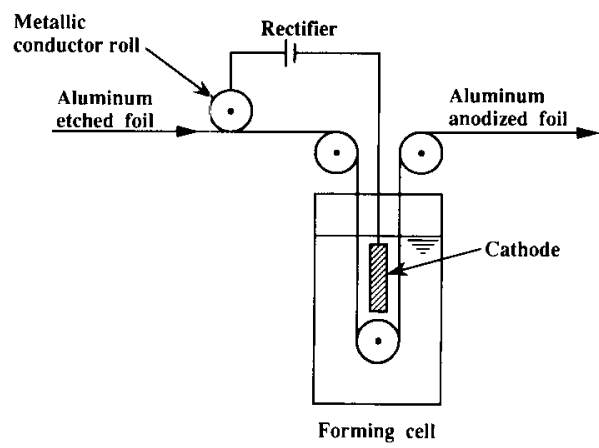

Fig. 1 Schematic drawing of conventional anodizing process of aluminum foil for electrolytic capacitor. 
を有する $\mathrm{IrO}_{2} / \mathrm{Ti}$ 型 DSE が液中給電槽用陽極として 有望と考え, 主として低圧電解コンデンサー用アルミ箔 の新しい液中給電化成法の開発と奏用化研究を行なった ので ${ }^{5 \sim 8)}$ ，その内容を以下に報告する.

\section{1 給電槽電解液の選定}

\section{2 実験と方法}

低圧コンデンサー用アルミ箔の化成は，アジピン酸了 ンモニウムなどの有機酸水溶液中で行なわれることが多 い. また液中給電化成法に於ける浓中給電槽の電解液は, 電解液の污染を防ぐためにも化成椣の電解液と共通にす ることが好ましく, 従って液中給電槽の電解液にはアジ ピン酸アンモニウム水溶液を用いることとした。

\section{2 供試電極の作成}

液中給電槽で用いられる陽極としては，アジピン酸ア ンモニウム水溶液を酸化分解させずに，水の分解反応即 ち酸素発生を選択優先的に行う電極種を選定する必要が ある。

DSE 型複合酸化物被覆金属電極として，触媒被覆層 各々約 $3 \mu \mathrm{m}$ の $\mathrm{RuO}_{2} / \mathrm{Ti}, \mathrm{IrO}_{2} / \mathrm{Ti}$ およびIrO $\mathrm{I}_{2}+\mathrm{Ta}_{2} \mathrm{O}_{5}$ $/ \mathrm{Ti}$ 電極を各々熱分解法 ${ }^{9}$ てで作成し供試電極とした。 ま た比較のために，厚さ約 $1 \mathrm{~mm} の$ 白金板電極(純度 $99.9 \%$ 以上，田中貴金属工業社製）およで厚さ約 $10 \mathrm{~mm}$ のグ ラファイト板電極（東海カーボン礼製）を睡入し各々を 供試電極とした。

\section{3 電解特性試験}

各供試電極の $100 \mathrm{~g} ・ \mathrm{dm}^{-3}$ のアジピン酸アンモニウ ム水溶液 $\left(30^{\circ} \mathrm{C}\right)$ 中での陽極電位を, カレントインタラ プター法にて測定した。

次に, $50 \mathrm{~g} ・ \mathrm{dm}^{-3}$ のアジピン酸アンモニウム水溶液 $\left(40^{\circ} \mathrm{C}\right)$ で満たされた小型試験電解槽を用いて電解を行 ない,アジピン酸アンモニウム水楁液の安定性並びに電 極の耐久性について検討した。

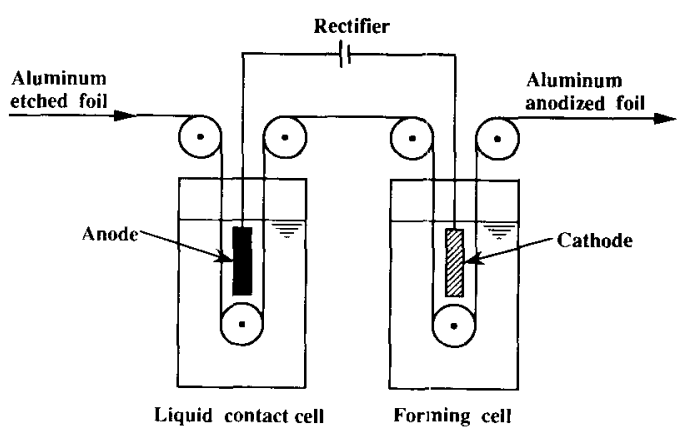

Fig. 2 Schematic drawing of new anodizing process of aluminum foil for electrolytic capacitor.

\section{4 アルミ箔の水素脆化}

アルミ箔が陰分極され水素脆化を受ける際の化成䇴の 静電容量に与える影響について検討した.

電解アルミコンデンサーに使用される純度 $99.8 \%$ 以 上厚さ約 $90 \mu \mathrm{m}$ のエッチド箔（LA $95 \mathrm{Al}$ ) を入手し陰 極之し, $\mathrm{IrO}_{2}+\mathrm{Ta}_{2} \mathrm{O}_{5} / \mathrm{Ti}$ 電極を陽極に用い, $50 \mathrm{~g}$ ・ $\mathrm{dm}^{-3}$ のアジピン酸アンモニウム水溶液中で電解温度を $20 \sim 60^{\circ} \mathrm{C}$ の範囲で変え, $5 \mathrm{~A} ・ \mathrm{dm}^{-2}$ で 8 分間エッチド 䇴を陰分極処理した.

次に，陰分極させた各種エッチド箔を $50 \mathrm{~g} ・ \mathrm{dm}^{-3}$ の アジピン酸アンモニウム水溶液で満たされた小型ビーカー 試験槽の中で，極間電圧が $50 \mathrm{~V}$ になる迄 $60^{\circ} \mathrm{C}$ で陽分極 させ化成処理を行ない化成簿とし，通常の製品化成箔評 価方法により静電容量を測定した. 静電容量測定法の概 要は, 化成箔を $200 \mathrm{~g} ・ \mathrm{dm}^{-3}, 30^{\circ} \mathrm{C}$ のアジピン酸アン モ二ウム水溶液中でキャパシタンスメーターを用い 120 $\mathrm{Hz}$ の直流等価回路で静電容量を测定するすのである.

\section{1 陽極電位}

\section{3 結果之考察}

アジピン酸アンモニゥム水楁液に於ける各供試電極の 電流-電位特性を Fig. 3 に示す.

白金電極㧍よびグラファイト電極はともに高い陽極電 位を示し, また電流密度依存性が高いことが認められた。

-方, $\mathrm{RuO}_{2} / \mathrm{Ti}, \mathrm{IrO}_{2} / \mathrm{Ti}$ 㧍よび $\mathrm{IrO}_{2}+\mathrm{Ta}_{2} \mathrm{O}_{5} / \mathrm{Ti}$ の 3 種類の DSE 型電極は, 何れる白金電極およびグラ ファイト電極に此べ遥かに低い陽極電位を示し，アジピ ン酸アンモニウム水溶液中での陽極過電圧は小さいこと が認められた，中でも $\mathrm{IrO}_{2}+\mathrm{Ta}_{2} \mathrm{O}_{5} / \mathrm{Ti}$ 電極は, 高電 流密度下でも安定した低い陽極電位を保持していること が認められた。

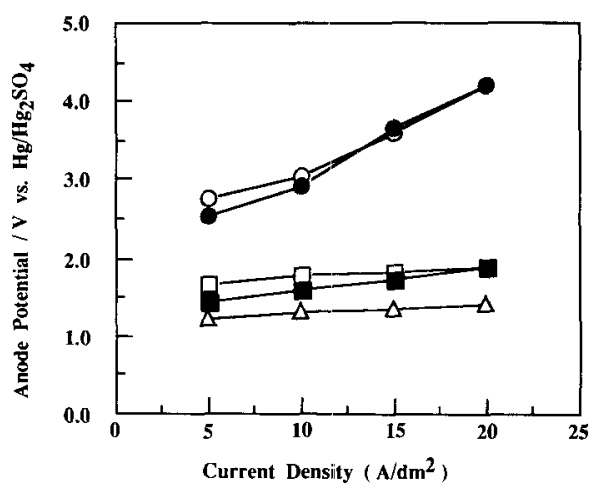

Fig. 3 Current-potential curves of five different electrodes in $100 \mathrm{~g} / 1$ ammonium adipate at $30^{\circ} \mathrm{C}$. $\mathrm{O}:$ Pt-plate, $\mathbf{0}$ Graphite, $\mathbf{\square}: \mathrm{RuO}_{2} / \mathrm{Ti}, \square: \mathrm{IrO}_{2} /$ $\mathrm{Ti}, \triangle: \mathrm{IrO}_{2}+\mathrm{Ta}_{2} \mathrm{O}_{5} / \mathrm{Ti}$. 


\section{2 電解液の安定性並びに電極の耐久性}

電解液の安定性並びに笛極の耐久性に関し榆討した結 果を Table 1 に示す.

$\mathrm{RuO}_{2} / \mathrm{Ti}, \quad \mathrm{IrO}_{2} / \mathrm{Ti}$ および $\mathrm{IrO}_{2}+\mathrm{Ta}_{2} \mathrm{O}_{5} / \mathrm{Ti} の 3$ 種類の DSE 型電極を各々用いて電解した結果, 電解液 は各々電解初期と比べ殆んど变化なく安定していた。

一方，白金電極拈よびグラファイト電極を各々用いて 電解した結果, 電解液は上もにアジピン酸アンモニウム 水溶液の電気化学的分解反汒によるもの上思われる油状 物質により液面が覆われ缌臭も漂っていた。

これは, 陽極過電圧の高い電極を有機酸水溶液中で用 いたために，比較的容易にKolbe 電解酸化反応のよう な陽極酸化反応が起きるためと考えられ，おそらく，ア ジピン酸が陽極酸化を受けセバシン酸または酪酸などが 生成しているためと思われる㣗年 ${ }^{12)}$. 一方, 陽極過電圧 の低い電極を用いた場合は, 有機酸塩の陽極酸化分解が 㸡制され，水の分解反応が選択的に優先されているるの と思われる。

電極の耐久性に関しては, 白金電極㧍よびグラファイ 卜電極ともに耐久性にそしかったが, $\mathrm{RuO}_{2} / \mathrm{Ti}$ を除く 二つの DSE 型電極には高い耐久性が認められ, 特に $\mathrm{IrO}_{2}+\mathrm{Ta}_{2} \mathrm{O}_{5} / \mathrm{Ti}$ 型 DSE が一番耐久性に優れていた。

\section{3 エッチド筞の唅分極による影篦}

給電槽の中で生ずるアルミ箔の陰分極作用が化成箔の 静電容量に及ぼす影響について検討した結果の一例を Fig. 4 に示す.

Fig. 4 に示すように，化成箔の静電容量は液中給電 槽の温度に大きく依存することが認められた。これはア ルミ箔が液中給電槽の中で陰分極される際, 水素脆化の 影響を大きく受けるためと思われる.

しかしながら, Fig. 40結果が示すように, 液中給電 槽の電解液温度を $30 \pm 5$ 'Cの範囲に保持することにより, 化成簿の静電容量に影響を与えない程度までアルミ䈃の 水素脆化を別制することが可能であることが分かった。 これらの結果をむとに, 液中給電槽の電解液温度を厳密 に管理し化成箔を製造した結果，従来法（金属ロール給 電法）に比較し逘色のない静電容量を持つ化成箔を制造 しうることが, 製品化成䈃の評佂結果から確認できた。

Table 1 Result of durability test for sample electrodes at $10 \mathrm{~A} / \mathrm{dm}^{2}, 40^{\circ} \mathrm{C}$.

\begin{tabular}{lcl}
\hline \multicolumn{1}{c}{ Electrode } & $\begin{array}{c}\text { Service life } \\
\text { (days) }\end{array}$ & Electrolyte stability \\
\hline Pt-plate & 7 & Unstable \\
$\mathrm{Graphite}_{\mathrm{RuO}_{2} / \mathrm{Ti}}$ & $<1$ & Unstable \\
$\mathrm{IrO}_{2} / \mathrm{Ti}$ & 5 & Stable \\
$\mathrm{IrO}_{2}+\mathrm{Ta}_{2} \mathrm{O}_{5} / \mathrm{Ti}$ & 60 & Stable \\
\hline
\end{tabular}

\section{4 プラントテスト}

低圧電解コンデンサー用アルミ箔のロール給電法化成 実機ラインを液中給電法に改造し, 实際の運転条件で操 業し，ロール給電法による化成箔之比べ䈹特性上抙色無 い䇴を製造することができるかを確認した。

先ず, 既存のロール給電法化成機の化成槽の一つを液 中給電槽に改造し，さらに液中給電槽の電解温度を厳密 に管理できるように，新たに Fig. 5 に示すような電解 温度管理システムを液中給電槽に取り付けた。

液中給電槽の電解液は $50 \mathrm{~g} ・ \mathrm{dm}^{-3}$ のアジピン酸アン モニウム水溶液とし，陽極には $\mathrm{IrO}_{2}+\mathrm{Ta}_{2} \mathrm{O}_{5} / \mathrm{Ti}$ 型 DSE を使用し，以下に示す電解条件でプラントテスト を行なった。

・アルミ簿コイル幅 : $500 \mathrm{~mm}$

・アルミ箔走行速度 : $0.2 \sim 1.4 \mathrm{~m} / \mathrm{min}$.

・負荷電流 : DC, Max. 1,600 A

・化成槽電解液 : $30 \sim 50 \mathrm{~g} ・ \mathrm{dm}^{-3}$ アジピン酸アンモニ ウム水溶液

・液中給電槽電解液 : $50 \mathrm{~g} ・ \mathrm{dm}^{-3}$ のアジピン酸アンモ 二ウム水溶液

- 陽極種 : $\mathrm{IrO}_{2}+\mathrm{Tel}_{2} \mathrm{O}_{5} / \mathrm{Ti}$ 型 $\mathrm{DSE}$

-電流密度 : $8 \mathrm{~A} / \mathrm{dm}^{2}$ (at $1,600 \mathrm{~A}$ )

・用途：低圧用電解コンデンサー

\section{5 プラントテスト結果}

約 14 ケ月のプラントテストの結果, ロール給電法に 比へ負荷電流を 20〜30\%増すことができ，それに比例 した化成処理速度む、上げることができ，単位時間当たり の化成処理量を大幅に増加できることが確認できた。

また，箔の溶断や電気的短絡事故もプラントテスト期

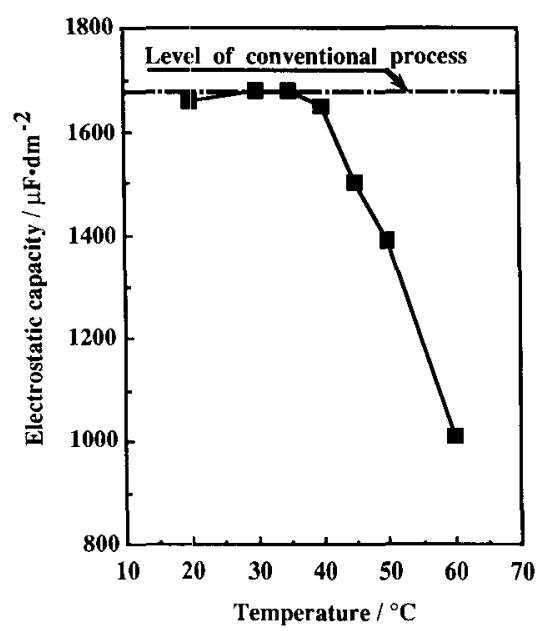

Fig. 4 Effect of the electrolyte temperature in the liquid contact cell on the electrostatic capacity of anodized aluminum foil.

Electrolyte : $50 \mathrm{~g} / \mathrm{l}$ Ammonium adipate. 


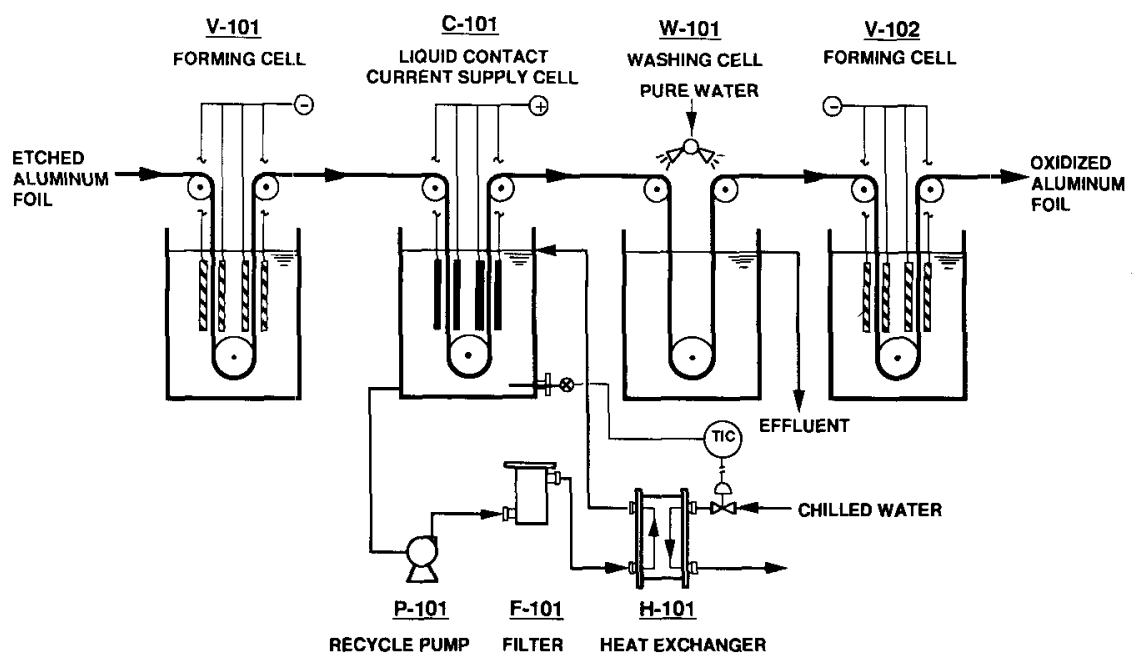

Fig. 5 Schematic drawing of liquid contact cell process with DSE for commercial plant.

間中全く経験せず，得られた化成䈃の特性む従来品之比 ベ全く遜色無い品質である事が確認された。

さらに，液中給電槽で用いられた $\mathrm{IrO}_{2}+\mathrm{Ta}_{2} \mathrm{O}_{5} / \mathrm{Ti}$ 型 DSE は，プラントテスト期間中, 平均 $8 \mathrm{~A} ・ \mathrm{dm}^{-2}$ で稼僖したが，この間の電極電位の変化並びに液中給電 槽の電解液の変化は全く認められず, 安定した操業を続 けることができた。

\section{4 結 害}

$\mathrm{IrO}_{2}+\mathrm{Ta}_{2} \mathrm{O}_{5} / \mathrm{Ti}$ 型 DSE を用いてコンデンサー用 アルミ箔の連続液中給電化成法について検討した結果, 陽極過電圧が非常に小さい DSE 型電極を液中給電槽の 陽極として用いることにより，1 年以上液中給電槽の電 槽電圧を上昇させずに，また液中給電槽の中の電解液を 分解させることなく，長期に亘り安定した操業を続けら れる事が分かった。

さらに, 従来不可能とされていたアルミ箔の陰分極に よる水素脆化の問題についても, 液中給電槽の温度管理 を厳密に行うことにより，コンデンサー特性に影響を及 ぼさない程度まで抑制できる事を見出し， $\mathrm{IrO}_{2}+\mathrm{Ta}_{2} \mathrm{O}_{5}$ /Ti 型 DSE による新しいアルミ箔の液中給電連続化成 処理法の実用化への足掛かりを呞むことができた ${ }^{13 \sim 14)}$.

ロール給電法から液中給電法への転換は比較的容易に, 既存化成ラインの改造で十分行えることがプラントテス トの結果確かめられたので, $\mathrm{IrO}_{2}+\mathrm{Ta}_{2} \mathrm{O}_{5} / \mathrm{Ti}$ 型 DSE によるアルミ箔の液中給電化成法は, コンデンサー用ア
ルミ箔需要に合わせてフレキシブルに生産調整できる技 術として, また夜間の無人化操業を可能ならしめる省力 化技術として, 今後の電解コンデンサー用アルミ䇴化成 製造分野に大きく貢献するものと確信する.

\section{文献}

1) E. Herrmann, Aluminium, 29, 465 (1953).

2) E. F. Barkman, Symposium on Anodizing Aluminium, Aluminium. Federation, p. 115 (1967).

3）林 美克，実務表面技術，29，453（1982）.

4）森輝男，実務表面技術，33，177（1986）.

5）島宗孝之，中島保夫，中松秀司，表面技術，42，783 (1991).

6）中島保夫，勝田修平，中松秀司，島宗孝之，電気化学協 会, 第 18 回電解技術㣙論会, 講演要旨集, p. 21 (1994).

7) 中島保夫, 脇田修平, 中松秀司, 島宗孝之, 電気化学, 64, 80 (1996)

8）中島保夫，中松秀司，島宗孝之，山川祜康，船越 明， 丸山俊朗，ソーダ之塩素，46，316 (1995).

9）ヘンリー・ベルナール・ベア，特公昭 46-21884 (1971).

10）加藤和夫, 传藤則雄, 関根太郎, 電気化学, 50,914 (1982).

11) A. Gozlan and A. Zilkha, Eur. Polym. J., 23, 133 (1987).

12) Z. Ogumi, H. Yamashita, K. Nishio, Z. Takehara and S. Yoshizawa, Electrochimica Acta., 28, 1687 (1983).

13）中松秀司, 島宗孝之, 特公昭 63-30996 (1988).

14) S. Nakamatsu and T. Shimamune, U.S.P. 4589959 (1986). 